\title{
Expected and Unexpected Developments of European Integration in the Field of Direct Taxes
}

\author{
Prof. dr. Pasquale Pistone, Associate Professor of Tax Law in the University of Salerno (Italy) and EURYI-ESF Professor at the
}

Wirtschaftsuniversität Vienna (Austria)

Tax systems should be drafted in a clear and consistent way, thus allowing for proper interpretation and application of their rules. Over the past decades market forces have put a considerable pressure on European institutions in order to remove tax barriers within the Internal Market. EU Member States have fiercely opposed this process of integration, which may harm the integrity of their own national tax sovereignties. The need for unanimous Council decisions has almost paralysed positive integration of direct taxes. By contrast, negative integration kept developing and establishing limits on cross-border direct taxation, thus showing the need for positive integration.

The friction between these two forces gave rise to a hectic and unstable process of legal development, which has turned European tax law into an area of high legal uncertainty and (in some cases of) inconsistency.

Despite the efforts of the two key players of European tax law - i.e. the European Commission and the European Court of Justice - to reconcile such conflicting forces, unpredictable and alternate developments in the integration of direct taxes often arise, negatively affecting cross-border situations within the Internal Market and in the relations with third countries.

Legal stability and predictability in the development of European tax law are needed just as much as the removal of tax barriers: all goals that at present seem far from being reached.

Before the end of 2006 the European Commission released three communications in the field of direct taxes ${ }^{1}$ and the European Court of Justice decided three important cases, namely ACT Group Litigation, ${ }^{2}$ Franked Investment Income ${ }^{3}$ and Denkavit France. ${ }^{4}$ Will such developments steer the rudder of positive and negative integration of direct taxes again in the direction of progress and evolution, or will they instead contribute to lead European law principles towards regress and involution?

Since 2001 the EU Commission has considerably intensified its activity on cross-border direct taxation in order to revitalise positive integration without compromising national sovereignties of the Member States. Based on the principle of subsidiarity and on Article 293.2 EC Treaty, this new approach confirms that even when unilateral action by the Member States is unable to remove the existing obstacles to crossborder activities, secondary law becomes necessary only insofar as co-ordination among EU Member States fails.

Tax co-ordination has therefore turned into the main axe of positive integration of direct taxes. COM (2001) 582 announced a two-track strategy based on targeted measures - which should address the most urgent problems in the short- and mid-term - and comprehensive solutions, focused instead on the most complex issues, such as the building up of an EU-wide common tax base and the solution to conflicts with double tax treaties.

However, the framework communication released by the European Commission on 19 December 2006 reported on just one of the two expected long-term developments, when announcing that a comprehensive legislative proposal for a common consolidated corporate tax base (CCCTB) will be presented by $2008 .{ }^{5}$ CCCTB is indeed the hardcore of the new tax co-ordination strategy and therefore we all hope that such proposal will open up a new era for the positive integration of direct taxes, like the one that took valueadded tax to a harmonised taxable base with the issuing of the Sixth VAT Directive in 1977.

\section{Notes}

COM (2006) 823 of 19 December 2006, Coordinating Member States' direct tax systems in the Internal Market. COM (2006) 824 of 19 December 2006, Tax Treatment of Losses in Cross-Border Situations; COM (2006) 825 of 19 December 2006, Exit taxation and the need for coordination of Member States' tax policies.

ECJ, 12 December 2006, case C-374/04, ACT Group Litigation Order (ACT GLO).

ECJ, 12 December 2006, case C-446/04, Franked Investment Income (FII).

ECJ, 14 December 2006, case C-170/05, Denkavit Internationaal BV and Denkavit France.

COM (2006) 823, p. 3. 
COM (2006) 823 does not contain any statement in respect of tax treaties, though the European Commission had announced five years ago that it intended, 'following technical discussions with Member States, to come forward in 2004 with a communication on the need to adapt certain provisions of double taxation conventions based on the OECD model to comply with Treaty principles. This will constitute a first step towards the possible elaboration of an EU model tax treaty'. ${ }^{6}$

How can the unexpected silence of COM (2006) 823 on tax treaties be interpreted and explained? We are all aware that technical communications and workshops have been organised at various levels by the European Commission for the purpose of facilitating tax coordination among EU Member States. However, the only effective co-ordination that took place was maybe the one among Member States aimed at opposing the European Commission's attempts to analyse critical issues arising in the relations with tax treaties. The Member States' lack of consensus for positive integration of direct taxes is the main reason for the failure of the expected co-ordination of tax treaties in the direction of European law. Nevertheless, it is submitted, Member States will not succeed in keeping the status quo of double tax conventions: all they may get is to lose the only effective way of contributing to the drafting of EU-compatible tax treaty provisions before the European Court of Justice strikes some of the existing ones down. No one should be tempted to believe that the position taken by the ECJ on LOB clauses in the ACT GLO decision may show the Court's intention to overcome the problems of compatibility with fundamental freedoms raised by tax treaties. The arguments reported in the following pages of this editorial, as well as another article contained in this issue of this Review, will give our readers some evidence of how urgent positive integration of tax treaties in Europe is. "Appropriate coordination and co-operation can enable Member States to attain their tax policy goals and protect their bases, thus making tax system better contributing to the success of the Internal Market, enhancing the competitiveness of EU business at the global level in line with the renewed Lisbon strategy', as the Commission says in COM (2006) $823 .^{7}$ This is indeed true and correct, but it is high time that the expected and needed action replaces long repeated slogans. Perhaps, the European Commission has not yet lost the match. Perhaps, action aimed at countering abuse or double taxation, or an extension of the arbitration convention will be decisive to revitalise positive integration and effectively tackle the conflict between tax treaties and European law.

The other two communications released on 19 December 2006 focus on the short- and medium-term goals of tax co-ordination, giving Member States guidance on the ECJ case law concerning exit taxes and a solution to make cross-border loss relief compatible with negative integration of direct taxes.

Guidance on exit taxes was certainly expected among the targeted measures announced in 2001 in respect of the relevant case law of the European Court of Justice. However, the actual content of the communication (2006) 825 does not completely match that of the de Laysterie and $\mathrm{N}$ decisions. On the one hand, the communication does not reflect all implications of the pan-European approach contained in the $N$ decision, perhaps because of the short lapse of time between the dates in which the decision and the communication were respectively issued. On the other hand, the two decisions focused on individuals, whereas the communication has a broader scope (including the potential impact on companies) and also focuses on issues, such as the transfer of assets, which have so far never been specifically analysed by the European Court of Justice. Rather than guiding Member States on case law, this communication seems instead to provide its own interpretation of the problems of compatibility: a matter that may easily interfere with the function exclusively attributed to the European Court of Justice. The conflict could become real as soon as the next case on exit taxes is decided by the ECJ.

The communication should instead be positively evaluated for authentically interpreting the Merger Directive's silence on the transfer of assets not connected to a permanent establishment. Except for this function, the value and impact of this communication are likely to be very limited: it will remain a mere technical statement on constantly evolving issues, which can be directly drawn from an analysis of the ECJ case law.

Also the communication on cross-border relief of losses was expected among the targeted measures announced by the Commission in 2001. Guidance on the relevant case law of the European Court of Justice is here the mere starting point to build up an EU compatible reform of loss relief within a company or a group of companies. Consequently, although an overlap with future case law of the European Court of Justice may in principle never be excluded, this communication does not interfere with the Court's function and makes loss relief also cross-border consistent, thus intervening where unilateral action of Member States would otherwise fail.

Despite the attempts of the European Commission, facts show that positive integration of direct taxes has considerably slowed down its process of development. By contrast, negative integration keeps developing fast. In 2006 the European Court of Justice decided twenty cases in the field of direct taxes: a record that proves how significant this domain has become and how much importance the European Court of Justice has gained within the process of integration.

\section{Notes}

COM (2001) 582, p. 15

COM (2006) 823, cit., p. 8. 
The legacy of Advocate General Geelhoed was contained in his Opinions on five important direct tax cases. After the première of the Kerckhaert-Morres decision, ${ }^{8}$ the Court decided all other cases before the end of 2006 (except for the Thin Cap GLO) without substantially sharing his new vision of cross-border direct taxation. Despite his attempts to soften the impact of fundamental freedoms with his thorough elaboration, none of the three recent decisions (ACT GLO, FII and Denkavit) contains any reference to disparities, dislocations and quasi-restrictions, which therefore remain a theoretical expression. This is perhaps a first important issue arising from the analysis of such decisions, which for many other aspects instead follow the specific (correct and incorrect) inputs given by Advocate General Geelhoed.

All three cases deal with cross-border flows of dividends, respectively outbound in Denkavit France and ACT GLO and inbound in FII, whereas in the latter two cases problems of compatibility with fundamental freedoms were caused by the mechanism of Advance Corporation Tax. Such cases clearly prove the complexity of facts that the European Court of Justice must take into account when interpreting European law. In some cases undesirable technical mistakes can be prevented by more heavily relying on the national judge, just like the ECJ is correctly doing in respect of an increasing number of preliminary questions. After all we should not forget that the ECJ's function is merely to interpret European law, whereas domestic and treaty law belong to fact-finding just as much as all other relevant facts of a preliminary ruling procedure do.

The ACT GLO case essentially raised three issues of compatibility, respectively involving the non-entitlement to indirect tax credit for outgoing dividends, a most-favoured-nation issue and the application of the limitation-on-benefits clause in the United KingdomNetherlands tax treaty.

The first issue was decided in the sense suggested by Advocate General Geelhoed, though on the basis of different arguments, reproducing the essence of the pan-European approach first applied in the Manninen decision (though in the State of residence) and clearly showing the ECJ's opposition for the approach used by the EFTA Court in its Fokus Bank decision.

The clear and expected answer on the second issue, totally in line with the $D$ decision, may be the reason for a serious factual mistake in analysing the LOB issue, which the Court (following in this respect the likewise wrong analysis of Advocate General Geelhoed) unduly and superficially assimilated to a mostfavoured-nation problem. Unlike argued by the Court in the ACT GLO decision, it is instead evident that most-favoured-nation and limitation-on-benefits clauses raise structurally different issues. In the case of MFN the taxpayer claims the application of a (more favourable) tax treaty without being a resident of either Contracting State. By contrast, in the case of LOB clauses the taxpayer is a resident of a Contracting State, who loses the entitlement to the benefits of the tax treaty between the country of source and his country of residence for the fact of being controlled by a resident taxpayer of yet another State. Consequently, stating, as the Court did in the ACT GLO decision, ${ }^{9}$ that 'even where such provisions extend to ... a company which is not resident in one of the Contracting Member States, they apply only to persons resident in one of those Member States and....are an integral part of them' in fact seems to ignore that technically, insofar as the LOB argument is concerned, the taxpayer is indeed a Dutch resident company that would be entitled to treaty benefits if the UK-Netherlands tax treaty hadn't included an LOB clause and if the Dutch company hadn't been controlled by a German resident shareholder. Consequently, rather than wrongly equating the facts of MFN and LOB clauses, the Court should have remembered that 'as far as the exercise of the power of taxation so allocated is concerned, the Member States nevertheless may not disregard Community rules. According to the settled case law of the Court, although direct taxation is a matter for the Member States, they must nevertheless exercise their taxation powers consistently with Community law'. ${ }^{10}$ From that perspective the correct precedent for a decision on the LOB issue was the open skies case law, ${ }^{11}$ in which the Court, right after quoting the Saint-Gobain decision (and thus implicitly proving that there is no difference between air-traffic agreements and tax treaties in this respect), held that nationality clauses contained in US air-traffic agreements with various EU Member States were incompatible with fundamental freedoms. Furthermore, the Court totally failed to gather the anti-abuse function of LOB clauses. Consequently, difficulties could also arise in comparing the Court's position on LOB clauses with that on the Cadbury Schweppes decision, ${ }^{12}$ which dealt with controlled foreign companies, though from the perspective of the State of residence of the shareholder. Could controlled foreign companies be legitimately limited by tax treaties through LOB, whereas their immediate taxation in the hands of their shareholders on the basis of CFC legislation is likely to be incompatible with fundamental freedoms? Although there are various types of CFC legislation and of LOB clauses, two generally opposite views on the same

\section{Notes}

8 ECJ, 14 November 2006, case C-513/04, Kerckhaert-Morres.

ECJ, 12 December 2006, ACT GLO, para. 90.

10 ECJ, 21 September 1999, case C-307/97, Saint-Gobain, para. 57. Not surprisingly, the ECJ did invoke this precedent also in the decision on the Denkavit France case, para. 44

11 ECJ, 5 December 2002, joined cases C-466/98 and ff., Commission./United Kingdom et aa. [open skies].

12 ECJ, 12 September 2006, case C-196/04, Cadbury Schweppes. 
phenomenon seem fairly difficult to reconcile. Arguing that the issue of compatibility for LOB clauses does not arise from the perspective of the State of source would not be an answer, because the ACT GLO dealt with a problem involving two Member States, both equally obliged to respect the principle of Community loyalty.

Consequently, it would be likewise wrong to argue that the ACT GLO decision gives green light to tax treaties, which instead keep being bound by the primacy of European law. The biggest impact of such decision should be on the relations with the United States, which includes various types of LOB clauses in its bilateral treaties. EU and EEA countries - like Hungary, Poland and especially Iceland (possibly the closest one to the final signature) - which are currently negotiating new tax treaties with the United States including an LOB clause should therefore not give up their hopes, but only wait until the next case on LOB clauses makes its way to the European Court of Justice. This technically wrong and unexpected statement on the LOB issue clearly proves that not only it is difficult to reconcile the various decisions in the intricate and complex field of direct taxes, but sometimes it is also very hard for the ECJ to understand technicalities of direct taxation.

The FII decision is perhaps the longest one ever issued by the European Court of Justice in the field of direct taxes. The extreme length and complexity of such decision however reflect the way in which the nine preliminary questions were drafted by the UK national judge. The main questions focused on the dissuasive effect created by ACT in respect of outbound investment, raising possible problems of compatibility with fundamental freedoms (namely right of establishment and free movement of capital) and the parent-subsidiary directive on the tax treatment of dividends paid by foreign subsidiaries to UK resident companies. Furthermore, the Court was also asked to state on the scope of Article 57 (1) EC Treaty and the repayment obligation of sums unduly levied or benefits unduly claimed.

The Court has substantially confirmed its previous case law on at least three issues, such as (i) the compatibility with the parent-subsidiary directive, (ii) the offset of foreign tax with UK mainstream corporation tax and (iii) the conditions for repayment, though leaving it up to the national judge to ascertain when the criteria set by the ECJ for such repayment were in fact met. All other points raise instead some interesting and not entirely expected developments.

Perhaps, the most unexpected developments concern the methods for relieving economic double taxation.

First, different relief methods may coexist in crossborder and domestic situations. This shows that - at least in the near future - the ECJ is not likely to impose capital import neutrality within the Internal Market.
Consistently with its previous case law the Court requires that credit should be given for foreign taxes up to the effective tax rate that is applicable to domesticsourced dividends. One may therefore wonder whether a pursuing capital export neutrality will be able affordable in the future.

Second, even more unexpected is the hiatus that the Court (not following the Opinion of Advocate General Geelhoed) has created between Articles 43 and 56 EC Treaty when stating that the additional administrative burden linked to imputation does not contravene the right of establishment, ${ }^{13}$ whereas no similar statement appears in respect of the free movement of capital. One may therefore be tempted to conclude that procedural restrictions are compatible with the right of establishment, but not with the free movement of capital. Such conclusion, however, does not reflect a different wording in the provisions contained in the EC Treaty and would end up in giving a stronger protection to portfolio investments (i.e. those below 10\%). Furthermore, this interpretation would depart from the traditionally homogeneous application of fundamental freedoms in the field of direct taxation until now strongly affirmed by the European Court of Justice at least within the Internal Market.

Third, interesting developments also concern the scope of Article 57 (1). After confirming the relevance of the nomenclature of Annex I to Council Directive 88/361/EEC and its non-exhaustive nature, the FII decision concluded that restrictions on direct investment also include dividends derived from them. Furthermore, the Court made reference to the (nontax) Konle decision ${ }^{14}$ to affirm that Article 57 (1) also refers to measures that have been adopted after 31.12.1993, but that are identical to previous legislation, or that reduce (or eliminate) obstacles to the exercise of Community rights and freedoms.

Finally, the Denkavit France decision brings about two important and far-reaching developments.

First, from a State of source perspective, the Court held the view that resident and non-resident shareholders may be in a comparable situation regardless of whether the latter ones have a permanent establishment in that country, thus clearly extending the conclusion reached some years before in the SaintGobain decision.

Second, the Court has made it clear that treaties form part of the legal framework of a country; consequently, the right to levy a withholding tax on the basis of the applicable tax treaty does not make it possible for a State to apply a less favourable treatment than that that applies to a comparable domestic situation, such as the payment of dividends to a domestic shareholder. Consequently, if flows of dividends are exempted domestically, they must also be exempted when paid to foreign shareholders.

In other words, this decision proves once more that

\section{Notes}

13 ECJ, 12 December 2006, case C-446/04, para. 53.

14 ECJ, 1 June 1999, case C-302/97, Konle, paras. 52-53. 
developments of negative integration are in principle mostly in line with previous decisions and, as such, expected. Unclear and unfortunate statements in some decisions, based on wrong consideration of relevant facts - as in the case of LOB clauses - may occur from time to time. However, later decisions on similar cases can always clarify the relevant interpretation of European law. In the light of the analysis contained in this editorial, no one should therefore be tempted to conclude that the European Court of Justice is considering to slow down the pace of negative integration of direct taxes, or to give green light to tax treaties on the basis of the need to preserve their overall balance.

Should Member States wish to balance or limit negative integration, then they should accept and support the European Commission's initiatives to revitalise positive integration, which should exclusively focus on paths that have not yet been explored by the European Court of Justice, rather than providing guidance on its direct tax case law and thus doubling its exclusive function to interpret European law.

The question initially raised by this editorial should therefore be answered negatively, though action taken by the European Commission and the European Court of Justice at the end of 2006 indeed goes in the right direction. Progress in the integration of direct taxes will however only become possible when the European Court of Justice, the European Commission and all 27 EU Member States will act together, each in its respective function, to achieve full cross-border consistency of rules governing direct taxation within the Internal Market and in the relations with third countries. 